\title{
Chronic Kidney Disease, Stage 2
}

National Cancer Institute

\section{Source}

National Cancer Institute. Chronic Kidney Disease, Stage 2. NCI Thesaurus. Code C80388.

Long-standing and persistent renal disease with glomerular filtration rate (GFR) between $60-89 \mathrm{ml} / \mathrm{min}$. 